\title{
Dirençli Epilepside Düşük Glisemik İndeksli Diyet Tedavisi: Olgu Sunumu
}

\author{
Low Glycemic Index Treatment in Refractory Epilepsy: A case report
}

\author{
Fatma Ilgaz ${ }^{1}$, Ceren Günbey ${ }^{2}$, Didem Ardıçlı ${ }^{2,3}$, Dilek Yalnızoğlu², Meral Topçu²
}

Geliş tarihi/Received: 24.06.2019 • Kabul tarihi/Accepted: 23.08.2019

\section{ÖZET}

Yüksek oranda yağ, yeterli miktarda protein ve düşük karbonhidrat içeren ve açlıkta olduğu gibi vücudu glukoz yerine başlıca yağlardan enerji sağlayacak şekilde yönlendiren ketojenik diyet, geçmişten günümüze ilaca dirençli epilepsi hastalarının tedavisinde ilk akla gelen tedavi seçeneğidir. İlk olarak 1920'li yılların başında 'klasik ketojenik diyet’ ile başlayan geleneksel KD tedavisini, diyetin yeni etki mekanizmalarının keşfedilmesi ile birlikte 2000'li yılların başından itibaren ortaya çıkan ve daha az kısıtlama yapılan alternatif KD’ler izlemiştir. Alternatif diyetler çoğunlukla diyete uyumun azaldığı adölesan (12-18 yaş) dönemde tercih edilse de, ciddi davranış sorunları olan ve diyetten fayda görmesine rağmen diyete uyumun azalması nedeniyle nöbet kontrolü sağlanamayan daha küçük yaştaki çocuklarda da göz önünde bulundurulması gerekebilir. Bu alternatif KD’lerden birisi olan düşük glisemik indeks tedavisi (LGIT) kan glukoz düzeylerini minimal ve stabil düzeyde tutmayı amaçlar ve bu şekilde epileptik nöbetler kontrol altına alınır. LGIT, klasik KD’e oranla daha fazla karbonhidrat (enerjinin yaklaşık \%10’u, günde 40-60 g/gün düşük glisemik indeksli karbonhidratlar) ve protein (enerjinin \%25’i) alımına, dolayısı ile daha fazla besin tüketimine olanak sağlar. Bu olgu sunumunda, preadölesan dönemde olan ve hafif nöbet bulguları, şiddetli elektroansefalogram (EEG) bozukluğu ve davranış bozuklukları ile izlenen bir vakada, klasik KD uygulamasındaki zorluklar ve LGIT diyetine geçişin tedavinin etkinliği üzerindeki etkileri tartışılmıştır.

Anahtar kelimeler: Ketojenik diyet, dirençli epilepsi, düşük glisemik indeks tedavisi

\section{ABSTRACT}

The ketogenic diet (KD) is a well-established treatment choice in refractory epilepsy with a high fat, moderate protein and low carbohydrate content, which leads the body to provide energy primarily from fats instead of glucose. Initially, a traditional diet also known as 'classical ketogenic diet' was implemented at the beginning of 1920s. This was followed by more recent and less restrictive alternative KD treatments at the beginning of 2000s, after discovery of new mechanisms of action. Although alternative KDs have been commonly used during adolescence (between 12 to 18 years of age) when the compliance to therapy usually decreases, these diets should also be considered in younger children with severe behavioral problems or lower compliance if the child is responsive to dietary treatment. Low glycemic index treatment (LGIT), one of these alternative KDs, aims to control seizures by keeping blood glucose levels at a minimal and constant

1. İletişim/Correspondence: Hacettepe Üniversitesi Sağllk Bilimleri Fakültesi Beslenme ve Diyetetik Bölümü, Ankara, Türkiye

E-posta: fatma.celik@hacettepe.edu.tr • (1) https://orcid.org/0000-0002-6518-0255

2. Hacettepe Üniversitesi Tıp Fakültesi Çocuk Sağlığı ve Hastalıkları Anabilim Dalı, Çocuk Nörolojisi Bilim Dall, Ankara, Türkiye

(D) https://orcid.org/0000-0003-2244-828X

3. Keçiören Eğitim ve Araştırma Hastanesi, Çocuk Nörolojisi Bilim Dalı, Ankara, Türkiye

(D) https://orcid.org/0000-0001-7054-3623
4. Hacettepe Üniversitesi Tıp Fakültesi Çocuk Sağlığı ve Hastalıkları Anabilim Dalı, Çocuk Nörolojisi Bilim Dalı, Ankara, Türkiye (1) https://orcid.org/0000-0001-9294-4305

5. Hacettepe Üniversitesi Tıp Fakültesi Çocuk Sağlığı ve Hastalıkları Anabilim Dalı, Çocuk Nörolojisi Bilim Dall, Ankara, Türkiye

(1) https://orcid.org/0000-0003-0484-8888 
range. LGIT allows a liberalized carbohydrate (approximately 10\% of energy, equals to $40-60 \mathrm{~g} /$ day low glycemic index carbohydrates), protein (approximately 25\% of energy) and food intake compared to classical KD. In this case report, the challenges during implementation of a classical $\mathrm{KD}$ in a preadolescent child with mild symptoms of seizures, severe abnormal electroencephalogram (EEG) and behavioral problems, and the effects of switching from the classical KD to LGIT on treatment efficacy were discussed.

Keywords: Ketogenic diet, refractory epilepsy, low glysemic index treatment

\section{Gíriş}

Ketojenik diyetler (KD), açlık metabolizmasında olduğu gibi vücudu glukoz yerine başlica yağlardan enerji sağlayacak şekilde yönlendiren ve bu şekilde epileptik nöbetlerin kontrolünü sağlayan, yüksek oranda yağ, büyümeyi sağlayacak düzeyde protein ve düşük karbonhidrat içeren diyetlerdir. Ketojenik diyetler epilepsi tedavisinde yaygin olarak kullanılmakla birlikte, bazı doğumsal glukoz transportu ve metabolizması bozukluklarında da etkin ve önemli bir tedavi yaklaşımıdır (1).

Geçmişten günümüze kadar epilepsinin tedavisinde farklı diyet yaklaşımları kullanılmıştır. İlk olarak 1921 yllında yüksek yağlı diyetle sağlanan ketozisin, açlığın yarattığı yararlı etkileri sağlayabileceği ileri sürülmüş ve 'klasik ketojenik diyet' tanımı ortaya atılmıştır (2). Ancak klasik KD’nin doğası gereği kısıtlı olması ve hastalar tarafindan diyete uyumun zaman içerisinde azalması nedeniyle sonraki yıllarda daha az kısıtlı olan ve daha fazla besin alımına olanak sağlayan 'alternatif ketojenik diyetler' keşfedilmiştir $(3,4)$.

Alternatif $\mathrm{KD}$ tedavilerinden birisi olan düşük glisemik indeks tedavisi [Low Glycemic Index Treatment (LGIT)] 2002 yllında Pfeifer ve Thiele (3) tarafından geliştirilmiştir. Geçmiş ylllarda KD alan çocuklarda kan şekeri düzeylerinin, uzamış açlık dönemlerinde dahi belirgin olarak stabil seyrettiği ve bu çocukların kan şekerindeki ufak dalgalanmalara (diyette belirtilenden fazla karbonhidrat alımı vb) karşı oldukça duyarlı oldukları belirlenmiş ve bu gözlemler sonucunda KD’nin kan şekeri düzeylerini stabilize ederek, antikonvülsan etki gösterebileceği ileri sürülmüştür $(5,6)$.
Düşük glisemik indeks (Gİ) tedavisinin amacı Gí<50 olan karbonhidrat kaynaklarını kullanarak hastanın kan şekeri düzeylerini minimal düzeyde ve stabil tutmaktır. Toplam karbonhidrat alımı, vücudun enerji için yağları kullanmaya başladığı fizyolojik eşik olan 40-60 g/gün ile sinırlandırılır. Serum keton düzeyleri genellikle minimal artış gösterir. Diyete açlık ya da hastanede yatışına gerek duyulmadan başlanabilir (7). Enerji gereksinimi besin tüketim kayıtlarından, yaşa özgü tahmini enerji gereksinimlerinden ya da bazal metabolik hız denklemlerinden yola çıkılarak hesaplanabilir. Diyetin ketojenik oranı (diyet yağının toplam karbonhidrat ve proteine oranı) yaklaşık 1:1'dir (enerjinin yaklaşık \%10'u karbonhidrat, \%25’i protein ve \%65’i yağ). Karbonhidrat alımı gün içerisinde öğünlere dağıtılmalı ve öğünün Gİnin düşürülmesi için bir protein ve/veya yağ kaynağ ile birlikte alınmalıdır (3,7). Vitamin ve mineral desteği, diyetle ortalama alım düzeyi belirlenerek bireysel olarak değerlendirilmeli ve yeterli sıvı alımı sağlanmalıdır (1).

Ketojenik diyetin farklı seçenekleri arasında diyetin etkinliği açısından önemli bir fark bulunmadığından, diyet türü seçiminde etkinlik algısından çok çocuğun yaşı, besin tercihleri, ailenin olanakları ya da KD merkezinin deneyimleri gibi faktörler göz önüne alınarak bireysel bazda karar verilmelidir. Son yayınlanan Uluslararası Ketojenik Diyet Çalışma Grubu önerilerinde çoğunlukla diyete uyumun azaldığı adölesan (12-18 yaş) dönemde, klasik diyet yerine Modifiye Edilmiş Atkins Diyeti (MAD) ya da LGIT gibi daha az kısıtlayıcı seçeneklerin tercih edilebileceği belirtilmiştir (1). 
Literatürde alternatif KD’ler çoğunlukla adölesan ve yetişkin gruplarda tercih edilse de diyetten fayda gören ancak uyum sorunu yaşayan daha küçük yaş gruplarında da denenebilir. Bu olgu sunumunda dirençli epilepsi ve ciddi davranış sorunları bulunan 8 yaşındaki bir kız olguda klasik KD uygulaması sırasında yaşanan zorluklar ve LGIT tedavisine geçişin diyete uyum ve diyet etkinliği üzerindeki etkileri incelenmiştir.

\section{OLGU SUNUMU}

Sekiz yaş dokuz aylık kız olgu merkezimize ilaca dirençli epilepsi nedeniyle başvurdu. Hikayesinden konuşma ve öğrenme güçlüğü (tatil döneminde okuma-yazma becerilerinde gerileme, sinıf tekrarı), davranış sorunları ile dikkat eksikliği ve hiperaktivite nedeniyle 6 yaşından itibaren Çocuk Ruh Sağlığı Bölümü’nde takipli olduğu, gözlerini bir noktaya dikme ve boş bakma şeklinde nöbetlerinin 7 yaşında başladığı öğrenildi. Levetirasetam, klobazam, valproik asit ve vigabatrin tedavilerine rağmen günlük nöbetleri devam eden hastanın hastanemizde 24 saatlik elektroensefalografi (EEG) incelemesinde multifokal epileptiform deşarjlar ve yavaş uykuda elektriksel status epileptikus (ESES) paterni görüldü. Hasta merkezimize başvurduğunda konuşma, yürüme ve öz bakım becerilerinde gecikme (ilk anlamlı kelimeler 3 yaşında, desteksiz yürüme 2 yaşında, öz bakım becerileri 6 yaş civarında), öğrenme güçlüğü mevcuttu. Vagal sinir stimülasyonu açısından da değerlendirilen hastaya, KD tedavisi başlandı.

KD öncesinde hastadan alınan besin tüketim kayıtlarından günde 4 öğün beslendiği, iştahının iyi olduğu, daha çok karbonhidrat içeriği yüksek besinlerle beslendiği, et ve sebze tüketiminin sinırlı olduğu, besin alerjisinin ya da gastrointestinal sisteme ilişkin bir şikayetinin olmadığı (kabızlık, ishal, gaz, intolerans), besin takviyesi kullanmadiğı ve daha önce özel bir diyet uygulamadığı belirlendi. Vücut ağırlı̆̆ı $27 \mathrm{~kg}$ (45. persentil), boyu $131.5 \mathrm{~cm}$ (51. persentil) olan hastanın büyüme parametreleri normal sinırlardaydl. Hastanın fiziksel aktivite düzeyi hafifti.
Hastada öncelikle klasik KD denendi. Diyet öncesi hastanın ortalama enerji alımı (3 günlük besin tüketim kaydı), yaşa göre tahmini enerji gereksinimi, fiziksel aktivitesi (hafif) ve büyüme trendi (normal) göz önüne alınarak enerji gereksinimi 1400 kkal/gün olarak belirlendi (Tablo 1). Hastanın yaşının büyük olması nedeniyle uyum ve tolerasyon açısından ketojenik diyet oranı 3:1 olarak planlandı. Diyet öncesi öğün sıklığı ve klasik KD’de porsiyonların genellikle küçük olması göz önünde bulundurularak beslenme planı 4 öğün şeklinde düzenlendi.

Diyet öncesinde anneye diyetin uygulanmasina ve izlemine ilişkin detaylı bir eğitim verildi. Ketojenik diyete hastane yatışı ve açlık fazı uygulanmadan, herhangi bir enerji kısıtlaması yapılmadan ev ortamında kademeli olarak oran artışı yapılarak başlanarak (ilk gün 1:1 oranı, sonrasında her gün/ gün aşırı 0.5 birim artırılarak sırasıyla 1.5:1, 2:1, 2.5:1 ve 3:1), hedeflenen $\mathrm{KD}$ oranına 5 . günde ulaşıldı. Hastaya tablet formunda multivitamin ve mineral takviyesi, kalsiyum ve D vitamini takviyesi ile jel kapsül formunda balık yağı takviyesine başlandı. İlaç ve takviyelerden gelen karbonhidrat miktarı <300 $\mathrm{mg} /$ gün olduğundan diyette herhangi bir düzeltme yapılmadı. Böbrek taşı ve asidoz riskini önlemek açısından sıvı alımı önemli olduğundan, herhangi bir kısıtlama yapılmadan hastanın günde $1650 \mathrm{~mL}$ sıvı alması planlandı (Tablo 1).

Kıbrıs’ta yaşayan aile, diyeti daha kontrollü uygulayabilmek için ilk iki ay Türkiye'de kaldı ve kan keton seviyeleri yakın takip edildi. Bu süreçte diyet aile tarafindan düzenli olarak uygulandı. Kan keton seviyeleri günlük olarak takip edildi, şehir dışında olmaları nedeniyle telefon ve mail yoluyla görüşüldü. Diyete başlangıç sonrasında herhangi bir akut yan etki (bulantı, kusma, asidoz vb.) olmadı. KD süresince hastanın nöbeti olmadı, algısının daha iyi olduğu ve davranış sorunlarının azaldığı gözlendi.

İlk iki ayın sonunda ailenin yeniden Kıbrıs'a dönmesi ile hastanın diyete uyumu geriledi, kan keton düzeyleri düştü. İlk aşamada diyetin enerjisi artırılıp, diyet oranı düşürüldü (1500 kkal/gün, 
Tablo 1. Hasta için planlanan klasik ketojenik diyetin içeriği

\begin{tabular}{|c|c|}
\hline Diyet bileşenleri: & Miktar: \\
\hline Diyet öncesi tüketim kayıtlarından (3 günlük) hesaplanan ortalama enerji alımı & 1300 kkal/gün \\
\hline Yaşa göre tahmini enerji gereksiniminin (EAR) \%80-90’ $1^{\mathrm{a}}$ & 1400-1570 kkal/gün \\
\hline Klasik ketojenik diyet için planlanan diyet enerjisib & $1400 \mathrm{kkal} / g u ̈ n$ \\
\hline Diyet oranı (yağ: [karbonhidrat ve protein]) ${ }^{c}$ & $3: 1$ \\
\hline Öğün sayısı ${ }^{\mathrm{d}}$ & 4 öğün \\
\hline Protein gereksinimi & $1 \mathrm{~g} / \mathrm{kg} / \mathrm{gün}, 27 \mathrm{~g} /$ gün (6.8 g/öğün) \\
\hline Diyet birimi (toplam)e & 45 \\
\hline Diyetin karbonhidrat miktarl ${ }^{\mathrm{f}}$ & 18 g/gün (4.5 g/öğün) \\
\hline Diyetin yağ miktarı ${ }^{\mathrm{f}}$ & 135 g/gün (33.8 g/öğün) \\
\hline Sivl gereksinmesi ${ }^{g}$ & 1650 mL/gün \\
\hline
\end{tabular}

${ }^{a}$ EAR:Estimated average requirement (yaşa göre tahmini enerji gereksinimi)

${ }^{b} Y u ̈ k s e k$ yağlı diyetlerin termik etkisinin daha düşük olması nedeniyle büyümesi normal olan çocuklarda tahmini enerji gereksiniminin \%80-90’ ile başlanabilir (diyet öncesi tüketim kayıtlarından elde edilen ortalama enerji alımının altına düşülmeden), ancak her çocuk için kısıtlama yapılmasına gerek yoktur.

c19 ay - 12 yıl yaş grubunda başlangıçta anti-epileptik etkinlik açısından (nöbetsizlik) 4:1 oranı daha etkili ancak tolere edilebilirlik daha düşük olduğundan, uyum açısından başlangıçta 3:1 oranı tercih edilebilir.

${ }^{d}$ Klasik ketojenik diyette porsiyonlar çoğunlukla küçüktür. Slk öğün verilmesi porsiyon büyüklüğünün ve doygunluğun azalmasına neden olabilir. Hastanın ketojenik diyet öncesi öğün sıklğl (4 kez/gün) da göz önüne alınarak 3 veya 4 öğün şeklinde planlama yapılabilir.

${ }^{e}$ Diyet birimi, seçilen diyet oranındaki her bir makro besin ögesinin enerji içeriğinin toplanması ve toplam enerji gereksiniminin, diyet birimi başına düşen enerjiye

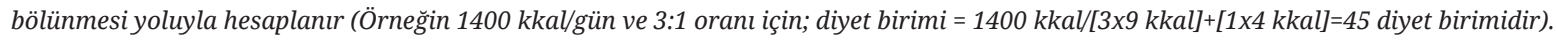

fToplam yağ alımının belirlenmesi için diyet birimi, diyet oranındaki yağın katsayısı ile çarpllır (45 diyet birimi x $3=135$ g/gün). Diyet birimi üzerinden hesaplanan toplam protein ve karbonhidrat alımindan (45 diyet birimi $x 1=45$ gram protein + karbonhidrat), protein gereksinimi düşülerek (27 g/gün), günlük alınması gereken karbonhidrat miktarl $(45-27=18$ g/gün) belirlenir.

${ }^{g}$ Slvl gereksinimi Holiday-Segar yöntemine göre hesaplanmıştır: Ağılllğl> 20 kg çocuklar için "1500 ml + 20 kg üzerindeki her 1 kg için +20 ml/kg/gün".

2.5:1 oranı). Diyetin tam uygulandığı ve etkili daha fazla tüketmek istemesi ve küçük porsiyonlarda ketozisin sağlandığı dönemde epileptik bulguların ve davranış sorunlarının düzelmesi, önemli bir yan etki görülmemesi ve çocuğun diyete yanıtlı olması göz önünde bulundurularak, katı olan klasik KD yerine alternatif bir diyete geçilmesi planlandı. Aileye alternatif KD’ler, içerikleri, uygulanması ve izlemi konusunda yeniden bilgi verildi. Görüşme sonunda hastanın özellikle karbonhidrat içeren besinleri doymaması göz önüne alınarak LGIT önerildi.

Çocuğun güncel vücut ağırlığı (28 kg, 46. persentil) ve boyu (134 cm, 57. persentil) yeniden değerlendirilerek, gereksinmeleri yeniden hesaplandl. Hastaya 1600 kkal LGIT planlandı ve yeniden tarifler oluşturularak aileye eğitim verildi (Tablo 2). Klasik KD sirasında gözlenen açlık hissi ya da diyet kaçamakları tekrarlanmadı. Diyetin altıncı ayında (LGIT sonrası

Tablo 2. Hasta için planlanan düşük glisemik indeksli diyet tedavisinin içeriği

\begin{tabular}{|c|c|}
\hline Diyet bileşenleri: & Miktar: \\
\hline Planlanan diyet enerjisi ${ }^{a}$ & 1600 kkal/gün \\
\hline Diyetin karbonhidrat (glisemik indeksi $<50$ ) miktarl ${ }^{b}$ & $40 \mathrm{~g} / \mathrm{gün}$ \\
\hline Diyetin yağ miktarı (enerjinin yaklaşık \%60’ı) & 110 g/gün \\
\hline Diyetin protein miktarı (enerjinin yaklaşık \%30’u) ${ }^{c}$ & $100-120 \mathrm{~g} /$ gün \\
\hline Diyet oranı (yağ: [karbonhidrat ve protein]) & $\sim 1: 1$ \\
\hline Sivi gereksinmesi ${ }^{\mathrm{d}}$ & 1650 mL/gün \\
\hline
\end{tabular}

${ }^{a}$ Ketojenik diyet sonrası mevcut ağırlık ve boy üzerinden gereksinimler yeniden hesaplanmıştır.

${ }^{b}$ Etkinlik görülmesi durumunda diyetin birinci ayından sonra kademeli olarak artırllabilir (en fazla $60 \mathrm{~g} / g u ̈ n$ ). Karbonhidrat alımına posa dahildir. Tüm karbonhidrat kaynaklarının glisemik indeksi <50 (düşük glisemik indeks) olmalıdır.

${ }^{c}$ Karbonhidrat kısitlamasina göre (40-60 g/gün karbonhidrat) düzenlenebilir.

¿Sıvı gereksinimi Holiday-Segar yöntemine göre hesaplanmıştır: Ağıllığl> 20 kg çocuklar için "1500 ml + 20 kg üzerindeki her 1 kg için +20 ml/kg/gün". 
üçüncü ay) çekilen EEG’de epileptik deşarjlarda $\% 50$ 'den fazla azalma izlendi.

Hasta iki yıl süresince diyeti uyguladı ve bu sürenin sonunda 6 ay içerisinde karbonhidrat alımı ayda 5-10 gr artırılıp, yă alımı 5-10 gram azaltılarak diyet kademeli olarak sonlandırıldı. Diyet süresince hastanın nöbeti olmadı, kullandığı üç antiepileptik ilaç kesildi ve kullandığı tek antiepileptik ilaç olan klobazam dozu azaltıldı. Öğretmenleri ve ailesi tarafindan sosyal uyum, fiziksel aktivite ve okul başarısında artış olduğunu belirtildi.

\section{TARTIŞMA}

Yüksek oranda yağ, yeterli miktarda protein ve düşük karbonhidrat içeriğine sahip olan KD’ler, 1920’li yllların başından günümüze kadar ilaca dirençli epilepsinin tedavisinde önemli bir yere sahiptir (1). $\mathrm{Bu}$ olgu sunumunda, preadölesan dönemde olan ve epilepsi, aktif hafif nöbet bulguları, şiddetli EEG bozukluğu ve davranış bozuklukları ile izlenen bir vakada, ketojenik diyet uygulamasındaki zorluklar ve diyetler arası geçişin (uyum sorunu vb. nedeniyle) diyetin etkinliği üzerindeki etkileri tartışılmıştır.

Ketojenik diyet doğası gereği katı ve kısıtlı bir diyet olması nedeniyle diyete uyum zaman içerisinde azalabilmekte ve diyet etkili olsa dahi bazı durumlarda hastalar/hasta yakınları diyeti sonlandırmayı isteyebilmektedir. Literatürde, klasik KD'den MAD ya da LGIT'ye geçildiğinde, nöbet kontrolünde herhangi bir bozulma olmadan diyetin daha serbest hale getirilebileceği gösterilmiştir $(3,4)$. Kossoff et al. (4)'un MAD uygulanan hastalarda diyetin etkinliğini değerlendirdikleri 6 hastalık bir vaka serisinde, klasik KD (3:1) uygulaması sonrası nöbet kontrolü, EEG'de normale yakın düzelme ve davranış sorunlarında iyileşme sağlanan bir hastada, diyetin birinci yılında uyum sorunları (diyetin katı olması) nedeniyle davranış sorunlarının geriye döndüğü ve EEG'nin yeniden bozulduğu saptanmıştır. Çalışmada, daha az kısıtlama yapılan alternatif bir diyete (MAD) geçtiklerinde, orta düzeyde sağlanan ketozisle birlikte daha ilk aydan itibaren nöbetlerin kontrol altına alındığı, davranış sorunlarının düzeldiği ve ilerleyen aylarda tüm antiepileptik ilaçların kesilerek, hastanın nöbetsiz olarak takip edildiği bildirilmiştir. Araştırmacılar, MAD gibi alternatif diyetlerin, özellikle davranış sorunu olan çocuklarda, daha kısıtlı ve katı bir diyet olan klasik KD'e tercih edilebileceğini önermiştir (4). Yine bazı çalışmalarda ilk 1-3 aylık daha katı bir diyetten sonra MAD ya da LGIT gibi daha serbest bir diyete geçildiğinde diyetin etkinliğinin sürdürülebileceği gösterilmiştir $(8,9)$.

Düşük glisemik indeks tedavisi toplam karbonhidrat alımını klasik KD ya da MAD kadar kısıtlamadan (günde 40-60 g), kan glukoz düzeylerini minimal ve stabil düzeyde tutarak nöbet kontrolü sağlayan bir diyettir (3). Henüz literatürde dirençli epilepsi hastalarında LGIT’nin etkinliğini, klasik KD veya antiepileptik ilaç tedavisi ile karşlaştıran randomize kontrollü bir çalışma yoktur. Bununla birlikte randomize olmayan klinik çalışmalarda LGIT’nin etkili olduğu $(3,10,11)$, ancak nöbetsizlik oranının diğer diyetlere oranla daha az olası olduğu gösterilmiş (10) ve özellikle katı diyetleri uygulamada zorluk yaşayan hastalarda alternatif olarak düşünülebileceği belirtilmiştir $(1,10,11)$.

$\mathrm{Bu}$ olgu sunumunda 3 aylık katı bir KD uygulaması sonrası yanıt alınan dirençli epilepsi hastasında, davranış ve uyum sorunları nedeniyle diyetin etkinliğinin azalması ve ailenin diyeti bırakmak istemesine rağmen, diyeti sonlandırmak yerine daha fazla serbestlik sağlayan alternatif bir diyete geçiş yapılmasının, hasta uyumu ve tedavi etkinliği üzerindeki etkileri gösterilmiştir. Klasik KD genellikle 'yüksek doz' bir tedavi seçeneği olarak düşünüldüğünden, genellikle birçok merkezde özellikle adölesan dönem öncesinde yaygın olarak tercih edilen bir tedavi seçeneğidir. Bu hastada da, başlangıçta hem ailenin daha planlı, detaylandırılmış ve açık talimatları olan bir diyet (değişim listeleri ve menü örnekleri yerine bilgisayarda hesaplanmış hazır tarifler üzerinden gidilmesi, tüm besinlerin tartılması, günlük keton izlemi vb.) uygulamak istemesi hem de çocuğun yaşının küçük olması göz önünde bulundurularak KD ekibi ile birlikte klasik 
KD tedavisi ile başlanmasına karar verilmiştir. Ancak diyetin tam olarak uygulandığı dönemde yan etki görülmeden etkinlik sağlanmasına rağmen, diyetin deneme süresinin bittiği üçüncü ayın sonunda uyumun azalması ile birlikte öğrenme güçlüğü ve davranış sorunlarının yeniden başlaması, okumayazma becerilerinin gerilemesi nedeniyle aile diyeti sonlandırmak istemiştir. Ketojenik diyet ekibinin diğer tedavi seçeneklerini gözden geçirmesi, literatürde benzer durumlarda alternatif diyetlere geçişin diyete uyumu ve etkinliği artırdığının bilinmesi ve ailenin alternatif diyetler konusunda bilgilendirilmesinden sonra, LGIT’ye geçiş yapılmıştır. Diyetin yeniden uygulanmaya başlanmasını takiben ilk birkaç hafta içerisinde yeniden etkinlik gözlenmiş ve diyet önerilen toplam uygulama süresi olan 2 yll süresince sorunsuz şekilde uygulanmıştır.

Sonuç olarak, farklı KD seçenekleri arasında diyetin etkinliği açısından önemli bir fark bulunmadığından, başlangıçta diyet türü seçiminde çocuğun yaşı, ailenin olanakları ya da KD merkezinin deneyimleri gibi faktörler göz önüne alınarak bireysel bazda karar verilmelidir. Ancak ilerleyen aylarda etkinlik görülmesine rağmen diyetin kısıtlamaları nedeniyle uyumun azalması ya da davranış sorunlarının görülmesi gibi durumlarda diyet sonlandırılmadan önce alternatif diyetlere geçişin göz önünde bulundurulması gereklidir.

Çıkar çatışması - Conflict of interest: Yazarlar çıkar çatışması olmadığını beyan ederler. - The authors declare that they have no conflict of interest.

\section{KAYNAKLAR}

1. Kossoff EH, Zupec-Kania BA, Auvin S, Ballaban-Gil KR, Christina Bergqvist AG, Blackford R, et al. Optimal clinical management of children receiving dietary therapies for epilepsy: Updated recommendations of the International Ketogenic Diet Study Group. Epilepsia Open. 2018;3(2):175-92.

2. Wilder RM. The effect on ketonemia on the course of epilepsy. Mayo Clin Bull. 1921;2:307.

3. Pfeifer HH, Lyczkowski DA, Thiele EA. Low glycemic index treatment: implementation and new insights into efficacy. Epilepsia. 2008;49(Suppl 8):42-5.

4. Kossoff EH, Krauss GL, McGrogan JR, Freeman JM. Efficacy of the Atkins diet as therapy for intractable epilepsy. Neurology. 2003;61:1789-91.

5. Greene AE, Todorova MT, McGowan R, Seyfried TN. Caloric restriction inhibits seizure susceptibility in epileptic EL mice by reducing blood glucose. Epilepsia. 2001;42:1371-8.

6. Huttenlocher PR. Ketonemia and seizures: metabolic and anticonvulsant effects of two ketogenic diets in childhood epilepsy. Pediatr Res. 1976;10:536-40.

7. Pfiefer HH. The low glycemic index treatment. In: Neal E (Editor) Dietary Treatment of Epilepsy: Practical Implementation of Ketogenic Therapy. $1^{\text {st }}$ ed. Chichester, West Sussex: Wiley-Blackwell, 2012:100-8.

8. Seo JH, Lee YM, Lee JS, Kang HC, Kim HD. Efficacy and tolerability of the ketogenic diet according to lipid-non lipids ratios_comparison of 3:1 with 4:1 diet. Epilepsia. 2007;48:801-5.

9. Kossoff EH, Turner Z, Bluml RM, Pyzik PL, Vining EP. A randomized, crossover comparison of daily carbohydrate limits using the modified Atkins diet. Epilepsy Behav. 2007;10:432-6.

10. Kim SH, Kang HC, Lee EJ, Lee JS, Kim HD. Low glycemic index treatment in patients with drug-resistant epilepsy. Brain Dev. 2017;39(8):687-92.

11. Karimzadeh P, Sedighi M, Beheshti M, Azargashb E, Ghofrani M, Abdollahe-Gorgi F.Low Glycemic Index Treatment in pediatric refractory epilepsy: the first Middle East report. Seizure. 2014;23(7):570-2. 